\title{
The assisting-approach of horseradish peroxidase immobilized onto amine-functionalized superparamagnetic iron oxide nanoparticles as a biocatalyst
}

\section{Basem E. Keshta}

Tanta University Faculty of Science

Ali H. Gemeay

Tanta University Faculty of Science

Abeer A. Khamis ( $\nabla$ abeer.khamis@science.tanta.edu.eg )

Tanta University Faculty of Science https://orcid.org/0000-0001-5216-2712

\section{Research Article}

Keywords: Horseradish peroxidase, immobilization, Enzymatic kinetic, 3- aminopropyl trimethoxysilane.

Posted Date: March 22nd, 2021

DOl: https://doi.org/10.21203/rs.3.rs-300199/v1

License: (c) (1) This work is licensed under a Creative Commons Attribution 4.0 International License.

Read Full License 


\section{Abstract}

To enhance the removal of dye, horseradish peroxidase (HRP) was immobilized onto aminefunctionalized superparamagnetic iron oxide and used as a biocatalyst for the oxidative degradation of Acid black-HC dye. The anchored enzyme was characterized by sets of techniques such as vibrating sample magnetometer, Fourier transform infrared, X-ray diffraction, thermogravimetric, scanning electron microscopy, BET and BJH methods, nitrogen adsorption-desorption measurements, Zeta potential, energy dispersive X-ray (EDX), and transmission electron microscopy. The Michaelis constant $(\mathrm{K} \mathrm{m}$ ) values of free peroxidase and immobilized horseradish peroxidase were determined that equal 4.5 and 5 $\mathrm{mM}$ for hydrogen peroxide; 12.5 and $10 \mathrm{mM}$ for guaiacol, respectively. Besides, the free peroxidase is thermally stable at $40^{\circ} \mathrm{C}$ however, the immobilized enzyme was up to $60^{\circ} \mathrm{C}$. In the catalytic experiment, the immobilized HRP showed superior catalytic activity compared with free HRP for the oxidative decolorization and removal of Acid black-HC dye. The impacts of experimental parameters for instance catalyst dosage, $\mathrm{pH}, \mathrm{H} 2 \mathrm{O} 2$ concentration, and temperature, were investigated. The reaction followed second-order kinetics and the thermodynamic activation parameters were determined.

\section{Introduction}

Enzymes are biocatalysts with excellent properties including high activity, selectivity, and specificity, which facilitate complex chemical reactions under the maximum benign experimental and environmental conditions (Ding et al. 2015; Min and Yoo 2014). The peroxidase enzymes are isolated from many plant sources such as horseradish and still cheapest than microbial production sources. Besides, they have a wide range of applications including Elisa kits, catalysis, and wastewater treatment. Also, they play a critical role in several industrial applications in analytical, agriculture, environmental, medical, etc. Peroxidases also have several uses in the treatment of pollutants such as phenols. Besides, organic syntheses as well as polymer synthesis and biosensor technology and alignment of paper and pulp, development of diagnostic kits and immunoassays. They are also used for adequate methods to estimate hydrogen peroxide In industrial and biological tests (Pandey et al. 2017; Rudra et al. 2008).

Freeform of enzymes is normally unstable, difficult to reuse, and are difficultly isolated from the substrate and the product. The immobilization of enzymes is a powerful tool for circumventing these disadvantages and providing better properties for practical applications. Most current procedures for purifying HRP are expensive and time-consuming conventional protein purification procedures with consequently low specific activities, yields, and folding purification processes (Bilal et al. 2017b). With the increased use of HRP in clinical and industrial applications, a simple, quick, and cost-effective purification procedure can easily be improved. Peroxidase has catalyzed pollutant transformation into other less dangerous compounds in laboratory-scale reactors in various effluents (Naghdi et al. 2018). Due to its high catalytic activity, commercial availability, broad substrates spectrum, and low costs for other enzymes, HRP is suited for dye degradation and decolorization (Yang 2017). The use of soluble and unbound enzymes is limited because they are cost-effective, reusable, balanced, sensitive to various denaturants, and are applied in non-stop reactors. To overcome these obstacles, the immobilization of 
enzymes has been approved in recent years as a way to promote the use of enzymes that are industrial, biological, and environmental (Sheldon and van Pelt 2013). Increased stability, activity, specificity, selectivity, decreased inhibition are not best achieved by immobilization but also enhance the enzyme's thermal stability, broaden the $\mathrm{pH}$ of the enzyme, and recovery of the product with a higher purity (Hoffmann et al. 2018; Min and Yoo 2014).

Different immobilization types of biocatalysts have been reported including; physical adsorption (Ali et al. 2018; Vineh et al. 2018a), covalent bonding (Vineh et al. 2018b), entrapment, cross-linking, and encapsulation (Bilal et al. 2017a; Bilal et al. 2017b). The immobilization of enzymes on the nanoparticles could increase their activities due to many reasons such as enzyme configuration, orientation, and density on the surface (Guzik et al. 2014; Zhang et al. 2011). Moreover, the morphology of nanoparticles could play a crucial role in impacting enzymatic improvement as well. Kumar et al. study demonstrated that epoxy Functional Polypropylene Films covalently immobilize HRP (Kumar et al. 2016). The films were practically applied in the catalytic degradation of basic red dye with about $90 \%$ removal. Bilal et al. were covalently immobilized HRP on calcium alginate via glutaraldehyde as a cross-linker agent with $85 \%$ immobilization efficiency (Bilal et al. 2016). Moreover, the immobilized HRP exhibited $99 \%$ of residual activity after $10 \mathrm{~min}$ and was used as a biocatalyst for the degradation of dyes. Nanayakkara et al. immobilized HRP on silica nanorods and unitized the resulting solid surface as an oxidative catalyst for the polymerization of substituted phenol (Nanayakkara et al. 2014). The supported enzyme exhibited substantial catalytic activity compared with the free enzyme. Moreover, three different shaped mesoporous silica nanoparticles were prepared and used to immobilize HRP and their catalytic activity was considered (Yang et al. 2018).

Recently, the immobilization of HRP onto magnetic supports was considered as an innovative strategy for the development of biocatalysts for wastewaters treatment (Donadelli et al. 2018). Magnetite nanoparticles' surface silanizing is the widely used approach for introducing surface functional groups (such as NH2) because of its properties, such as less-cytotoxicity, good stability, and ease of performance in organic and aqueous solvents (Hosseinifar et al. 2017; Ramalingam et al. 2018).

This work aims at developing a method that is consistent with the future application of HRP immobilization. To this effect, 3-aminopropyltrimethoxysilans were immobilized by HRP (APTMS). The biochemical characterization of the immobilized HRP was assessed and compared to those of the free HRP.

\section{Materials And Methods}

\subsection{Chemicals and reagents}

Ferrous sulfate heptahydrate, Anhydrous ferric chloride, sodium hydroxide, methyl alcohol, toluene, 3aminopropyltrimethoxy-silane (APTES) was bought from Alpha Aser for Chemicals. Horseradish (Armoracia rusticana) roots purchased locally. Hydrogen peroxide and guaiacol were purchased from Sigma Chemical. Acid black-HC (AB) dye was provided by Misr Spinning \& Weaving Company, El- 
Mahalla El-Kubra, Gharbia, Egypt under project cooperation with Tanta University with grant number TU03-16.

\subsection{Synthesis}

\subsubsection{Synthesis of amine-functionalized magnetite $\mathrm{NPs}\left(\mathrm{Fe}_{3} \mathrm{O}_{4} @ \mathrm{NH}_{2}\right)$}

$\mathrm{Fe}_{3} \mathrm{O}_{4} @ \mathrm{NH}_{2}$ was fabricated according to earlier published methods (Liu et al. 2013; Pasternack et al. 2008). Briefly, $2.5 \mathrm{~g}$ from the dried powder of $\mathrm{Fe}_{3} \mathrm{O}_{4} \mathrm{NPs}$, which was previously prepared in (Gemeay et al. 2019) was poured into $500 \mathrm{ml}$ mixed solvents from methanol /toluene with equal value. Subsequently, the solution mixture was dispersed for 30 minutes under sonication, followed by a gentle $10 \mathrm{ml}$ APTES addition. The reaction was kept under a mechanical overhead stirring at $70^{\circ} \mathrm{C}$ for 6 hours. The particles obtained were frequently washed by water, the latter washed by ethanol to produce a fine powder. The powder was then dried in an oven for 12 hours at $80^{\circ} \mathrm{C}$.

\subsubsection{Immobilization of HRP onto Fe304@NH2}

Firstly, the $\mathrm{Fe}_{3} \mathrm{O}_{4} @ \mathrm{NH}_{2} \mathrm{NPs}$ were washed repeatedly by doubled distilled water. The immobilization of HRP over the surface of Fe304@NH2. 4500 units of enzyme dissolved in $50 \mathrm{ml}$ acetate buffer were contained in $5 \mathrm{mg}$ enzyme, were gently mixed with the surface at room temperature (RT) overnight during an overnight. The supernatant was developed and the product (Fe304@NH2-HRP) dried for one night at RT (Mohamed et al. 2008).

\subsection{Characterization methods}

The functionalization and immobilization of HRP onto the magnetite surface were confirmed by using JASCO FT-IR-4100 (Japan) in the ú range of $4000-200 \mathrm{~cm}^{-1}$ and Shimadzu TG-50-TA (Japan) in the temperature range from $\left(25-800^{\circ} \mathrm{C}\right)$ with flow rate $5{ }^{\circ} \mathrm{C} / \mathrm{min}$ under $\mathrm{N}_{2}$ air. The crystalline structure of prepared samples was studied by using X-ray diffractometer GNR, APD 2000 PRO diffractometer (Italy). When the X-ray is operated with a current of beams of $40 \mathrm{kV}$ and $30 \mathrm{~mA}$ at $2 \theta=2-80^{\circ}$ at $0.05^{\circ}$ step speeds. The JCPDS database was also used to analyze the diffraction peaks achieved. The surface measurements of catalysts were recorded on Brunauer-Emmett-Teller (BET) NONA touch 4LX (USA), Barrett-Joyner- Halenda, and (BJH) NONA touch 4LX (USA). Zeta potential Inc. Santa Barbara, Calif (USA) confirmed the dispersion of catalyst in a solution. The magnetic properties of as-prepared samples were measured using handmade VSM (Tanta, Egypt) (El-Alaily et al. 2015). The UV-VIS T80+ double-beam has been used to monitor the $A B$ dye concentration in the solution. The morphology of catalyst surface, particle size, and elemental analysis were studied using TEM JEM-2100F (USA) and SEM FEI Quanta environmental integrated with octane silicon drift detector (SDD) delivers high-quality EDX data (EDAX, AMETEK).

\subsection{Kinetics measurements}


The addition of either $\mathrm{H}_{2} \mathrm{O}_{2}$ or the $\mathrm{Fe}_{3} \mathrm{O}_{4} @ \mathrm{NH}_{2}-\mathrm{HRP}$ separately to the $\mathrm{AB}$ dye solution does not affect the decolorization of the $A B$ dye. In contrast, if the $\mathrm{H}_{2} \mathrm{O}_{2}$ solution and the $\mathrm{Fe}_{3} \mathrm{O}_{4} @ \mathrm{NH}_{2}-\mathrm{HRP}$ were added at the same time to the $A B$ solution the decolorization process becomes remarkable. The decreasing of $A B$ concentration was followed using UV-Vis spectrophotometer at $\lambda \max =575 \mathrm{~nm}$. Moreover, the absorption time-output data were also fitted to the kinetic plot of the second order, Equation (1). Where the oxidation of $A B$ was executed in $250 \mathrm{~mL}$ Erlenmeyer flask present in shaker thermostat with speed $150 \mathrm{rpm}$. In detail, $300 \mathrm{mg}$ of $\mathrm{Fe}_{3} \mathrm{O}_{4} @ \mathrm{NH}_{2}-\mathrm{HRP}, 2.4 \times 10^{-4} \mathrm{M}$ of $\mathrm{AB}$, and $0.16 \mathrm{M}$ of $\mathrm{H}_{2} \mathrm{O}_{2}$ were added with shaking at the desired temperature. The supernatant was separated using a magnet at time intervals to follow the dye consumption calculated from Eq. (2).

$$
\begin{aligned}
& \frac{1}{[A]_{t}}-\frac{1}{[A]_{0}}=k t \\
& \text { Dye consumption }(\%)=\frac{A_{0}-A_{t}}{A_{0}} \times 100
\end{aligned}
$$

Where $A o$ is the dye absorbance at time 0 and $A_{t}$ is the dye absorbance at any time $t(\min )$.

\subsection{Partial purification of Horseradish Peroxidase}

We partially purified Egyptian HRP (Mohamed et al. 2008). HRP enzyme was extracted from horseradish roots about $(1 \mathrm{~kg}$ ) was cut into a cube and juiced using a blender for $10 \mathrm{~min}$. The extract was filtered with Whomman filtering paper and a centrifuged filter was made at $8000 \mathrm{rpm}, 25^{\circ} \mathrm{C}$ for 30 minutes. After centrifugation, the supernatant was identified as the crude extract, that fallen by ammonium sulfate (75 percent saturation). Centrifugation at $12000 \mathrm{Xg}$ for 20 minutes collected the precipitate, dissolved in 50 $\mathrm{ml}$ of distilled water, and dialyzed against successive distilled water change. The dialysate was centrifuged by a non-bound protein filter (porous size $0.45 \mu \mathrm{M}$, Millipore) at 15,000 Xg for 20 min to remove cell debris. The filtrate was lyophilized using Christ Alpha 1-5 lyophilizer overnight to obtain a powder form of horseradish peroxidase (Mohamed et al. 2008).

\subsection{Determination of peroxidase activity}

Peroxidase activity was examined spectrophotometrically by oxidation of guaiacol (2-methoxyphenyl) to tetraguaiacol at $470 \mathrm{~nm}$. (Tonami et al. 2004). The reaction mixture contained $1 \mathrm{~mL} 50 \mathrm{mM}$ acetate buffer ( $\mathrm{pH}$ 5.5), and $40 \mathrm{~mm}$ guaiacol, $8 \mathrm{mM} \mathrm{H}_{2} \mathrm{O}_{2}$, and enough enzyme. The absorption was considerably changed at $470 \mathrm{~nm}$ at RT because of the guaiacol oxidation. The reaction mixture was used as a control without the enzyme. Enzyme activity is indicated as a unit; the amount of the enzyme that can catalyze the oxidation of $1 \mu \mathrm{mol}$ of guaiacol per minute at $30^{\circ} \mathrm{C}$ is defined as 1 unit of peroxidase activity.

\subsection{Determination of protein}

The protein concentration in purified HRP was assessed using bovine serum albumin that was used as a standard by using the Bradford method (He 2011) Knowing that the protein concentration in the 
immobilized HRP was estimated by eliminating from immobilization the concentration of protein calculated in the supernatant before immobilization.

\subsection{The Immobilization of HRP onto amino-functionalized magnetite nanoparticles}

The enzyme was immobilized by carefully mixing the 3-aminopropyl-trimethoxysilane (APTMS) end-overend at RT overnight and then by re-washing the enzyme ( $5 \mathrm{mg}$ contained 4,500 unit) with distilled water dissolved in $50 \mathrm{ml}$ of $0.05 \mathrm{M}$ sodium acetate buffer $\mathrm{pH} 5.6$ overnight. the supernatant aliquots were pulled and dried for further analysis at RT. (Mohamed et al. 2008).

\subsection{Enzyme Characterization}

Enzyme characterization was performed on the free and immobilized enzyme, like Lineweaver-Burk reciprocal tracks for the Km peroxidase activity (Lineweaver and Burk 1934). The values from the slopes and intercepts on the curves have been calculated with Different $\mathrm{H} 2 \mathrm{O} 2$ and guaiacol substrates, ranging between 1.5 and $8 \mathrm{mM}$ and between 8 and $40 \mathrm{mM}$ respectively in acetate buffers (pH 5.6). To add to this, the $\mathrm{pH}$ profile was analyzed in various buffers types, including $50 \mathrm{mM}$ sodium citrate buffer $(\mathrm{pH} 3.0-4.0)$; sodium acetate buffer ( $\mathrm{pH}$ 5.0-5.6); sodium phosphate buffer ( $\mathrm{pH} 6.0-8.0)$, as well as Tris- $\mathrm{HCl}$ buffer ( $\mathrm{pH}$ 9) at $40^{\circ} \mathrm{C}$. Also, the temperature effect of the activity was analyzed from $10-70{ }^{\circ} \mathrm{C}$ and the optimal temperature for soluble and immobilized HRP was also measured. The residual activities of the enzyme were also measured at different temperatures between 30 and $80^{\circ} \mathrm{C}$, with thermal stability, after 30 minutes of incubation. Time intervals for the free and immobilized enzyme were also evaluated at the optimum temperature at $30^{\circ} \mathrm{C}$ and the immobilized peroxidase enzyme was evaluated for reusability.

\section{Results And Discussion}

\subsection{Characterization of catalyst}

\subsubsection{FT-IR analysis}

Figure 1 showed that the FT-IR spectra of $\mathrm{Fe}_{3} \mathrm{O}_{4}, \mathrm{Fe}_{3} \mathrm{O}_{4} @ \mathrm{NH}_{2}$, and $\mathrm{Fe}_{3} \mathrm{O}_{4} @ \mathrm{NH}_{2}-\mathrm{HRP}$. For all three samples the strong absorption bands around $420-600 \mathrm{~cm}^{-1}$ and $3465 \mathrm{~cm}^{-1}$ are due to $\mathrm{Fe}-\mathrm{O}$ vibration and Fe-OH stretching, respectively. The grafting of APTES over magnetite surface was confirmed from bands that appeared at 1430 and $2970 \mathrm{~cm}^{-1}$ corresponds to the bending and stretching of $-\mathrm{CH}_{2}$ group respectively. Besides, the band at $1048 \mathrm{~cm}^{-1}$ assigned to symmetric stretching of the $\mathrm{C}-0$ bond. The band at 3300 $\mathrm{cm}^{-1}$ asigned to $\mathrm{N}-\mathrm{H}$ stretching vibration of the terminal $\mathrm{NH}_{2}$ group of APTES molecules is expected but not observed due to its weak dipole moment (Araghi and Entezari 2015). The FTIR spectrum of $\mathrm{Fe}_{3} \mathrm{O}_{4} @ \mathrm{NH}_{2}-\mathrm{HRP}$ displayed the same characteristic bands as $\mathrm{Fe}_{3} \mathrm{O}_{4} @ \mathrm{NH}_{2}$ but there are two new bands around $1640 \mathrm{~cm}^{-1}$ and $\mathrm{C}=0$ and $\mathrm{C}=\mathrm{N}$ stretch $1430 \mathrm{~cm}-1$ assigned. This proves the immobilization of HRP over the $\mathrm{Fe}_{3} \mathrm{O}_{4} @ \mathrm{NH}_{2}$ surface was successful

\subsubsection{XRD pattern}


Figure 2 showed that the crystal structure of $\mathrm{Fe}_{3} \mathrm{O}_{4}, \mathrm{Fe}_{3} \mathrm{O}_{4} @ \mathrm{NH}_{2}$, and $\mathrm{Fe}_{3} \mathrm{O}_{4} @ \mathrm{NH}_{2}-\mathrm{HRP}$. For all three samples the general XRD peaks located at $2 \theta=18^{\circ}, 30.5^{\circ}, 35.5^{\circ}, 43^{\circ}, 57^{\circ}$, and $63^{\circ}$ assigned to (111), (2 20 ), (3 1 1), (4 00 ), (511) and (4 40 ) planes, respectively. These results agree with the magnetite database (JCPDS-19-0629) and confirm as-prepared magnetite is spinal cubic. The highly crystalline magnetite was kept stable after functionalization by APTES and HRP immobilization Because both materials have an amorphous structure (Phan and Jones 2006).

\subsubsection{VSM study}

Figure 3 shows the magnetization performance of $\mathrm{Fe}_{3} \mathrm{O}_{4}, \mathrm{Fe}_{3} \mathrm{O}_{4} @ \mathrm{NH}_{2}$, and $\mathrm{Fe}_{3} \mathrm{O}_{4} @ \mathrm{NH}_{2}-\mathrm{HRP}$ with zero remanences and coercively confirmed the prepared samples poses superparamagnetic behavior (Mutneja et al. 2016). Also, the magnetization saturation (Ms) values of $\mathrm{Fe}_{3} \mathrm{O}_{4}, \mathrm{Fe}_{3} \mathrm{O}_{4} @ \mathrm{NH}_{2}$, and $\mathrm{Fe}_{3} \mathrm{O}_{4} @ \mathrm{NH}_{2}-\mathrm{HRP}$ are $60.7 \mathrm{emu} / \mathrm{g}, 59.1 \mathrm{emu} / \mathrm{g}$, and $63.6 \mathrm{emu} / \mathrm{g}$ respectively. The coating of pristine magnetite by a non-magnetic substance like APTES leads to a decrease Ms value and in contrast after immobilization HRP that contains Fe ion in its chemical structure leads to an increased Ms value than pristine (Petcharoen and Sirivat 2012). These phenomena confirm successful functionalization and immobilization steps. In any case, this does not lose the samples their advantage in separation under the influence of magnets.

\subsubsection{TGA analysis}

Functionalization of APTES and immobilization of HRP over $\mathrm{Fe}_{3} \mathrm{O}_{4}$ surface were confirmed by TGA curves illustrated in Figure 4. For all three samples, general behavior appeared above $570{ }^{\circ} \mathrm{C}$ corresponds to phase transition from magnetite $\left(\mathrm{Fe}_{3} \mathrm{O}_{4}\right)$ to hematite ( $\mathrm{FeO}$ ) (Mahdavi et al. 2013). TGA curve of $\mathrm{Fe}_{3} \mathrm{O}_{4} @ \mathrm{NH}_{2}$ displays a large weight loss about $15 \%$ below $100{ }^{\circ} \mathrm{C}$ assigned to physically adsorbed water onto the surface followed by where weight loss of $7.1 \%$ in the temperature range $100-350{ }^{\circ} \mathrm{C}$ is possibly due to the breakdown of grafted APTES molecules on $\mathrm{Fe}_{3} \mathrm{O}_{4}$ (Araghi and Entezari 2015).

\subsubsection{BET, BJH, and Zeta potential measurements}

The BET specific surface area $\left(\mathrm{S}_{\mathrm{BET}}\right)$ of $\mathrm{Fe}_{3} \mathrm{O}_{4}$ and $\mathrm{Fe}_{3} \mathrm{O}_{4} @ \mathrm{NH}_{2}-\mathrm{HRP}$ are studied by the $\mathrm{N}_{2}$ adsorption/desorption method (Venkateswarlu et al. 2013). The $S_{\mathrm{BET}}$ was determined to be 102.7 and $86.66 \mathrm{~m}^{2} / \mathrm{g}$ respectively. The decreasing $\mathrm{S}_{\mathrm{BET}}$ value returns to the occupation of HRP to sites onto $\mathrm{Fe}_{3} \mathrm{O}_{4}$ surface (Sahoo et al. 2019). The isotherms of the two samples display hysteresis loops from type IV isotherm according to IUPAC classification and occurred at relative pressures between 0.70 and 1.0 so confirms the presence of mesoporous structure (Donohue and Aranovich 1999). Additionally, the porous nature and size distribution was determined by the Barret, Joyner, and Halenda method (BJH) by analysis of desorption isotherm with tabulating data obtained in Table 1. Further information about $\mathrm{Fe}_{3} \mathrm{O}_{4} @ \mathrm{NH}_{2}-$ HRP catalyst surface was achieved by measuring zeta potential. Where it has a positive value $(\zeta=23.23$ $\mathrm{mV}$ ) confirming the rapid coagulation of dispersed $\mathrm{Fe}_{3} \mathrm{O}_{4} @ \mathrm{NH}_{2}-\mathrm{HRP}$ in solution (Ladole et al. 2015). 
Table 1: Showing BJH data for estimating porous nature of $\mathrm{Fe}_{3} \mathrm{O}_{4}$ and $\mathrm{Fe}_{3} \mathrm{O}_{4} @ \mathrm{NH}_{2}-\mathrm{HRP}$

\begin{tabular}{lccccc}
\hline \multicolumn{1}{c}{ Sample } & $\begin{array}{c}\text { Surface area } \\
\mathbf{m} / \mathbf{g}\end{array}$ & $\begin{array}{c}\text { Pore Volume } \\
\mathbf{c c} / \mathbf{g}\end{array}$ & $\begin{array}{c}\text { Pore radius } \\
\text { nm }\end{array}$ & $\begin{array}{c}\mathrm{APR}^{*} \\
\mathrm{~nm}\end{array}$ & $\begin{array}{c}\text { TPV* } \\
\text { cc/g }\end{array}$ \\
\hline $\mathrm{Fe}_{3} \mathrm{O}_{4}$ & 47.64 & 0.16 & 1.93 & $3.82 \times 10^{3}$ & $1.97 \times 10^{-3}$ \\
$\mathrm{Fe}_{3} \mathrm{O}_{4} @ \mathrm{NH}_{2}-\mathrm{HRP}$ & 46.11 & 0.14 & 1.93 & $3.85 \times 10^{3}$ & $1.67 \times 10^{-3}$ \\
\hline
\end{tabular}

*APR is average pore radius $* \mathrm{TPV}$ is the total pore volume

\subsubsection{SEM and TEM studies}

The textural morphologies of $\mathrm{Fe}_{3} \mathrm{O}_{4}, \mathrm{Fe}_{3} \mathrm{O}_{4} @ \mathrm{NH}_{2}$, and $\mathrm{Fe}_{3} \mathrm{O}_{4} @ \mathrm{NH}_{2}-\mathrm{HRP}$ are displayed in Figures $5 \mathbf{a}, 5 \mathbf{b}$, $\mathbf{5 c}$, respectively. The images revealed a quasi-spherical structure with particle sizes below $70 \mathrm{~nm}$. The $\mathrm{Fe}_{3} \mathrm{O}_{4}$ surface becomes more smother after functionalization by APTES followed by little accumulation as a result of HRP addition (Ladole et al. 2015; Namdeo 2018). Further information about the samples was introduced after investigation samples by TEM as illustrated in Figures $\mathbf{5 d}$, 5e, and $\mathbf{5 f}$ (Enache et al. 2017). TEM images reveal agglomerated nano spherical morphology with an average grain size of 5-10 $\mathrm{nm}$ without increasing grain size after the immobilization step (Prasad et al. 2017). The crystal nature of $\mathrm{Fe}_{3} \mathrm{O}_{4}$ was confirmed by the HRTEM image (Ma et al. 2003; Tang et al. 2011).

3.3. The kinetic of the free and immobilized HRP

\subsubsection{The specific activity of the free and immobilized HRP}

With a retentions activity of 72 percent, the specific activity of immobilized HRP has increased 1.2 times between 3400 and $3149 \mathrm{U} / \mathrm{mg}$.

Table 2: the retention \& specific activities of the free and immobilized HRP.

\begin{tabular}{|c|c|c|c|c|}
\hline Step & $\begin{array}{c}\text { Protein Conc. } \\
\mathrm{mg} / \mathrm{g}\end{array}$ & $\begin{array}{c}\text { Enzyme activity } \\
\mathrm{U} / \mathrm{g}\end{array}$ & $\begin{array}{c}\text { Specific activity } \\
\mathrm{U} / \mathrm{mg}\end{array}$ & $\begin{array}{c}\text { Retention activity } \\
\%\end{array}$ \\
\hline Free HRP & 3.3 & 11000 & 3400 & - \\
\hline Immobilized HRP & 1.47 & 7920 & 4149 & \multicolumn{1}{|c}{} \\
\cline { 1 - 3 } & & &
\end{tabular}

\subsubsection{The Michaelis constant ( $\mathrm{Km})$ value of HRP activity}

The process of immobilization affects the distribution of the substrate to the active site of the enzyme (Mielgo et al. 2003). In this study, the $\mathrm{km}$ free and immobilized HRP values were determined to be 4.5 
and $5 \mathrm{mM}$ for $\mathrm{H}_{2} \mathrm{O}_{2}$, and 12.5, and $10 \mathrm{mM}$ respectively for guaiacol (Figure $6 \mathrm{a}, \mathrm{b}$ ) this indicated a greater substrate affinity than free enzymes to immobilized HRP.

\subsubsection{Effect of Temperature and $\mathrm{pH}$ on free and immobilized HRP activities}

The optima temperature on the HRP activity for the free and immobilized status of about $40^{\circ} \mathrm{C}$ was shown in (Figure 7a). This showed that the immobilized HRP was subject to temperature increase denaturation resistance. The immobilized enzyme maintained greater fractions of catalytic activities at higher temperatures compared to the free enzyme (Kulshrestha and Husain 2006).

Figure (7b) shows that the $\mathrm{pH}$ shows the essential ionization status of the significant proton groups that donate or accept in the catalyst site of the enzyme. The free and immobilized HRP pH activity profile with the same $\mathrm{pH}$ optimal as the acetate buffer is displayed at $\mathrm{pH}$ 5.6. But the immobilized enzyme maintained a relative HRP activity less than soluble at lower and high $\mathrm{pH}$ levels, but $\mathrm{pH}$ changes were susceptible with the immobile peroxidase compared to soluble peroxidase. This data agrees with (Diao et al. 2014) that most plant peroxidase has reported studies that have shown optimum activity between 4.5 and 6.0 in acidic areas.

Enzyme activity at the specific $\mathrm{pH}$ (or temperature)

Relative activity $(\%)=$ $\times 100$

Enzyme activity at the optimum $\mathrm{pH}$ (or temperature)

\subsubsection{Impact of Temperature on HRP stability}

To assess the thermal stability of the free and immobilized HRP, both enzymes were exposed to different temperatures $\left(30-80^{\circ} \mathrm{C}\right)$ were incubated for $30 \mathrm{~min}$ (Figure 8). The data demonstrated that HRPs are soluble and immobilized, respectively, at 40 and $50^{\circ} \mathrm{C}$. Whereas the soluble form showed a full loss for 30 minutes at $70^{\circ} \mathrm{C}$ after incubation, $25 \%$ of the HRP's activity remained immobilized. The immobilization thus resulted in significant thermostability increases. Furthermore, immobilized HRP on APTMS maintained full activity at $60^{\circ} \mathrm{C}$ for at least 2 hours, while free HRP activity decreased to nearly zero at the same temperature (Tupper et al. 2010). Likewise, immobilized turnip peroxidase which was incubated at $60^{\circ} \mathrm{C}$ for $2 \mathrm{~h}$ retained $54 \%$ of the initial enzyme activity, while in similar incubation conditions the soluble enzyme lost almost 83 percent of the original activity. (Xu and Wang 2010). The relative activity (\%) was calculated from the ratio of its activity after incubation to the activity under the optimum temperature of incubation.

\subsubsection{Time intervals in optimum temp at $30^{\circ} \mathrm{C}$ for free and immobilized HRP(Figure 9).}

\subsubsection{Reusability}


To assess the reusability of the immobilized HRP (Figure 10). The reaction mixture of the immobilized $\mathrm{HRP}$ after a single reaction cycle contained $1.0 \mathrm{ml}$ of $8 \mathrm{mM} \mathrm{H}_{2} \mathrm{O}_{2}, 40 \mathrm{mM}$ guaiacol, $50 \mathrm{mM}$ sodium acetate buffer $\mathrm{pH} 5.6$, and 0.1 unit of the enzyme was collected and washes with a sodium acetate buffer $\mathrm{pH} 5.6$ for removal of any residual substrate and added to the following reaction cycle. In each succeeding reaction cycle, the percentage of relative activity was calculated using the ratio of the enzyme activity to the first reaction cycle. The important advantages of the use of an immobilized biocatalyst are increased stability and easy separation of the bound peroxidase during washes (Mohamed et al. 2014).

\subsection{Kinetics of oxidative degradation of $A B$}

\subsubsection{Effect of $\mathrm{pH}$}

The oxidation rate of $\mathrm{AB}$ dye via $\mathrm{H}_{2} \mathrm{O}_{2}$ catalyzed through $\mathrm{Fe}_{3} \mathrm{O}_{4} @ \mathrm{NH}_{2}-\mathrm{HRP}$ was determined at different $\mathrm{pH}$. Where the $\mathrm{pH}$ of $\mathrm{AB}$ dye solution was set by acetate buffer at $\mathrm{pH}=5.6$. Subsequently, the other wanted $\mathrm{pH}$ values out of acetate buffer were achieved by (Carbonate-Bicarbonate buffer, $\mathrm{pH}=9.6$ ) and (Glycine $\mathrm{HCl}$ buffer, $\mathrm{pH}=2.6)$. As the oxidation rate of $\mathrm{AB}$ dye is decreased with increasing $\mathrm{pH}$ as revealed in Figure 11. This result will return to the Fenton reaction mechanism (Pereira et al. 2012).

\subsubsection{Effect of $[A B]$}

The dependency of the reaction rate on the $[A B]_{0}$ was calculated by changing its concentration between $1.6 \times 10^{-4} \mathrm{~mol} \mathrm{~L}^{-1}$ and $4 \times 10^{-4} \mathrm{~mol} \mathrm{~L}^{-1}$, whereas concentrations of other reaction constituents were kept constant. The dye consumption in the presence of $\mathrm{Fe}_{3} \mathrm{O}_{4} @ \mathrm{NH} 2-\mathrm{HRP}$ is shown as a function of time and a second-order graph for the reaction of oxidative degradation of $A B$ to $37^{\circ} \mathrm{C}$ is shown in Figure 12. Where values of the rate constants that are derived from the second-order plot were noted to decrease with increasing the concentration of $A B$ from $1.6 \times 10^{-4} \mathrm{~mol} \mathrm{~L}^{-1}$ to $4 \times 10^{-4} \mathrm{~mol} \mathrm{~L}^{-1}$. This performance can be attributed to the restricted number of radicals concerned in the oxidation process (Dulman et al. 2012).

\subsubsection{Effect of $\left[\mathrm{H}_{2} \mathrm{O}_{2}\right]$}

AB dye's oxidation rate depends on the first $\mathrm{H}_{2} \mathrm{O}_{2}$ concentration so; it was calculated by changing $\mathrm{H}_{2} \mathrm{O}_{2}$ concentration between 0.08 and $0.32 \mathrm{~mol} \mathrm{~L}^{-1}$ while keeping the concentration of other reactants constant. The second-order plots for the oxidative degradation reaction of $A B$ are shown in Figure 13. Here in the oxidation rate slightly decrease and increased again with increased $\left[\mathrm{H}_{2} \mathrm{O}_{2}\right]_{0}$. The tolerable explanation for this phenomena is the immobilized HRP consume a higher concentration from $\mathrm{H}_{2} \mathrm{O}_{2}$ to reach its maximum activity for ( ) production consumed in AB dye degradation (Zhu et al. 2011).

\subsubsection{Effect of temperature}

The effect of temperature on $A B$ dye decolorization was investigated over a temperature range of 20-37 ${ }^{\circ} \mathrm{C}$. The concentrations of $\mathrm{AB}, \mathrm{H}_{2} \mathrm{O}_{2}$, and $\mathrm{Fe}_{3} \mathrm{O}_{4} @ \mathrm{NH}_{2}-\mathrm{HRP}$ were set up constant at $0.16 \mathrm{~mol} \mathrm{~L}^{-1}, 2.4 \times 10^{-4}$ $\mathrm{mol} \mathrm{L}^{-1}$, and $300 \mathrm{mg} \mathrm{L}^{-1}$, respectively. Figure (14) displays increasing consumption of $A B$ as a function of 
time with the increasing temperature that confirms the oxidation process of $A B$ using $\mathrm{Fe}_{3} \mathrm{O}_{4} @ \mathrm{NH}_{2}-\mathrm{HRP}$ catalyst is endothermic.

On other hand, the thermodynamic activation parameters, $\Delta \mathrm{S}^{\#}$, and $\Delta \mathrm{H}^{\#}$ are computed from the intercept and the slope respectively based on Eq. (3) and Eyring plot, Figure (15). Besides, the activation energy $\left(E_{a}\right)$ and free energy $\left(\Delta G^{\#}\right)$ were estimated from Eqs. (4-5) and recorded in Table 3. Wherever the negative sign of entropy value specified the reaction from endothermic type.

$$
\begin{aligned}
\ln \left(\frac{\mathrm{k}}{\mathrm{T}}\right) & =-\frac{\Delta \mathrm{H}^{\#}}{\mathrm{RT}}+\ln \left(\frac{\mathrm{k}_{\mathrm{B}}}{\mathrm{h}}\right) \frac{\Delta \mathrm{S}^{\#}}{\mathrm{R}} \\
\mathrm{E}_{\mathrm{a}} & =\Delta \mathrm{H}^{\#}+\mathrm{RT}_{\text {exp }} \\
\Delta \mathrm{G}^{\#} & =\Delta \mathrm{H}^{\#}-\mathrm{T}_{\text {exp }} \Delta \mathrm{S}^{\#}
\end{aligned}
$$

As $h, k_{B}$ and $R$ are constants of Planck, Boltzmann, and ideal gas respectively. Anywhere $T_{\exp }$ is the average experimental temperature.

\begin{tabular}{|c|c|c|c|c|c|c|}
\hline Catalyst & $\begin{array}{l}\text { Temp } \\
{ }^{\circ} \mathrm{C}\end{array}$ & $\begin{array}{c}\mathrm{k} \times 10^{-3} \\
\mathrm{~L} \mathrm{~mol}^{-1} \mathrm{~min}^{-1} \\
\end{array}$ & 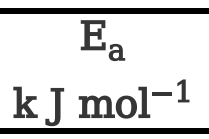 & $\begin{array}{c}\Delta \mathrm{H}^{\#} \\
\mathbf{k ~ J ~ \mathrm { mol } ^ { - 1 }} \\
\end{array}$ & $\begin{array}{c}\Delta \mathrm{G}^{\#} \\
\mathrm{k} \mathrm{J} \mathrm{\textrm {mol } ^ { - 1 }} \\
\end{array}$ & $\begin{array}{c}\Delta \mathrm{S}^{\#} \\
\mathrm{~J} \mathrm{~mol}^{-1} \mathrm{~K}^{-1} \\
\end{array}$ \\
\hline $\begin{array}{c}20 \\
\mathrm{Fe}_{3} \mathrm{O}_{4} @ \mathrm{NH}_{2}-\mathrm{HRP}\end{array}$ & $\begin{array}{c}1.93 \\
25\end{array}$ & 47.86 & 45.41 & 42.92 & -142.44 & 2.55 \\
\hline $\begin{array}{l}30 \\
37 \\
\end{array}$ & $\begin{array}{l}3.85 \\
5.53\end{array}$ & & & & & \\
\hline
\end{tabular}

Table 3 represents the $\mathrm{k}$ and the thermodynamic parameters of the oxidative consumption of AB.

\section{Conclusion}

In summary, $\mathrm{Fe}_{3} \mathrm{O}_{4}$ was prepared by the co-precipitation method followed by post functionalization by APTES. Encapsulation of HRP enzyme over $\mathrm{Fe}_{3} \mathrm{O}_{4} @ \mathrm{NH}_{2}$ surface was achieved in the immobilization step showing good operational, thermal, and storage stability compared with the free HRP. Where the oxidation process of $A B$ is endothermic. Meanwhile, the $A B$ dye degradation starting breakdown of azo $(N=N)$ linkage followed by oxidative cleavage of $\mathrm{C}$ and $\mathrm{S}$ bond of the $\mathrm{AC}$ dye by free radicals generated in the intermediate, and finally the carbon dioxide and water. The results of this study have demonstrated the applicability of using $\mathrm{Fe}_{3} \mathrm{O}_{4} @ \mathrm{NH}_{2}-\mathrm{HRP}$ as an effective biocatalyst for the treatment of an azo dye in an aqueous solution.

\section{Declarations}

Ethical Approval 
Not applicable.

\section{Consent to Participate}

Not applicable.

\section{Consent to Publish}

Not applicable.

\section{Authors Contributions}

BK: Methodology, Writing- Original draft preparation. AG: Conceptualization, Supervision, Investigation. AK: Formal analysis, Reviewing and Editing.

\section{Funding}

A research project funded by the Research Fund - Tanta University (TU-03-16).

\section{Competing Interests}

The authors declare that there is no conflict of interest.

\section{Availability of data and materials}

Please contact the authors for data requests.

\section{References}

Ali M, Husain Q, Sultana S, Ahmad M (2018) Immobilization of peroxidase on polypyrrole-cellulosegraphene oxide nanocomposite via non-covalent interactions for the degradation of Reactive Blue 4 dye Chemosphere 202:198-207

Araghi SH, Entezari MH (2015) Amino-functionalized silica magnetite nanoparticles for the simultaneous removal of pollutants from aqueous solution Applied Surface Science 333:68-77

Bilal M, Asgher M, Parra-Saldivar R, Hu H, Wang W, Zhang X, Iqbal HM (2017a) Immobilized ligninolytic enzymes: an innovative and environmental responsive technology to tackle dye-based industrial pollutants-a review Science of the Total Environment 576:646-659

Bilal M, Iqbal HM, Hu H, Wang W, Zhang X (2017b) Enhanced bio-catalytic performance and dye degradation potential of chitosan-encapsulated horseradish peroxidase in a packed bed reactor system Science of the Total Environment 575:1352-1360

Bilal M, Iqbal HM, Shah SZH, Hu H, Wang W, Zhang X (2016) Horseradish peroxidase-assisted approach to decolorize and detoxify dye pollutants in a packed bed bioreactor Journal of environmental 
Diao M, Ayékoué BNc, Dibala D, Dabonné S, Dicko MH (2014) Purification and characterization of sweet potato (Ipomoea Batatas) peroxidase Journal of Animal and Plant Sciences 22:3419-3432

Ding S, Cargill AA, Medintz IL, Claussen JC (2015) Increasing the activity of immobilized enzymes with nanoparticle conjugation Current Opinion in Biotechnology 34:242-250

Donadelli JA, Einschlag FSG, Laurenti E, Magnacca G, Carlos L (2018) Soybean peroxidase immobilized onto silica-coated superparamagnetic iron oxide nanoparticles: Effect of silica layer on the enzymatic activity Colloids and Surfaces B: Biointerfaces 161:654-661

Donohue MD, Aranovich G (1999) A new classification of isotherms for Gibbs adsorption of gases on solids Fluid Phase Equilibria 158:557-563

Dulman V, Cucu-Man SM, Olariu RI, Buhaceanu R, Dumitraş M, Bunia I (2012) A new heterogeneous catalytic system for decolorization and mineralization of Orange $\mathrm{G}$ acid dye based on hydrogen peroxide and a macroporous chelating polymer Dyes and Pigments 95:79-88

El-Alaily T, El-Nimr M, Saafan S, Kamel M, Meaz T, Assar S (2015) Construction and calibration of a low cost and fully automated vibrating sample magnetometer Journal of Magnetism and Magnetic Materials 386:25-30

Enache DF et al. (2017) Cysteine-functionalized silica-coated magnetite nanoparticles as potential nanoadsorbents Journal of Solid State Chemistry 253:318-328

Gemeay AH, Keshta BE, El-Sharkawy RG, Zaki AB (2019) Chemical insight into the adsorption of reactive wool dyes onto amine-functionalized magnetite/silica core-shell from industrial wastewaters Environmental Science and Pollution Research:1-18

Guzik U, Hupert-Kocurek K, Wojcieszyńska D (2014) Immobilization as a strategy for improving enzyme properties-application to oxidoreductases Molecules 19:8995-9018

He F (2011) Bradford protein assay Bio Protoc 101:e45

Hoffmann C et al. (2018) Experimental and computational evaluation of area selectively immobilized horseradish peroxidase in a microfluidic device Chemical Engineering Journal 332:16-23

Hosseinifar A, Shariaty-Niassar M, Seyyed Ebrahimi S, Moshref-Javadi M (2017) Synthesis, characterization, and application of partially blocked amine-functionalized magnetic nanoparticles Langmuir 33:14728-14737

Kulshrestha Y, Husain Q (2006) Bioaffinity-based an inexpensive and high yield procedure for the immobilization of turnip (Brassica rapa) peroxidase Biomolecular Engineering 23:291-297 
Kumar V, Misra N, Goel NK, Thakar R, Gupta J, Varshney L (2016) A horseradish peroxidase immobilized radiation grafted polymer matrix: a biocatalytic system for dye waste water treatment RSC advances 6:2974-2981

Ladole MR, Muley AB, Patil ID, Talib M, Parate VR (2015) Immobilization of tropizyme-P on aminofunctionalized magnetic nanoparticles for fruit juice clarification Journal of Biochemical Technology 5:838-845

Lineweaver H, Burk D (1934) The determination of enzyme dissociation constants Journal of the American chemical society $56: 658-666$

Liu Y, Li Y, Li X-M, He T (2013) Kinetics of (3-aminopropyl) triethoxylsilane (APTES) silanization of superparamagnetic iron oxide nanoparticles Langmuir 29:15275-15282

Ma M, Zhang Y, Yu W, Shen H-y, Zhang H-q, Gu N (2003) Preparation and characterization of magnetite nanoparticles coated by amino silane Colloids and Surfaces $A$ : physicochemical and engineering aspects 212:219-226

Mahdavi M, Ahmad MB, Haron MJ, Namvar F, Nadi B, Rahman MZA, Amin J (2013) Synthesis, surface modification and characterisation of biocompatible magnetic iron oxide nanoparticles for biomedical applications Molecules 18:7533-7548

Mielgo I, Palma C, Guisan J, Fernandez-Lafuente R, Moreira M, Feijoo G, Lema J (2003) Covalent immobilisation of manganese peroxidases $(\mathrm{MnP})$ from Phanerochaete chrysosporium and Bjerkandera sp. BOS55 Enzyme and Microbial Technology 32:769-775

Min K, Yoo YJ (2014) Recent progress in nanobiocatalysis for enzyme immobilization and its application Biotechnology and Bioprocess Engineering 19:553-567

Mohamed SA, Aly A, Mohamed TM, Salah HA (2008) Immobilization of horseradish peroxidase on nonwoven polyester fabric coated with chitosan Applied biochemistry and biotechnology 144:169-179

Mohamed TM, El-Souod SMA, Ali EM, El-Badry MO, El-Keiy MM, Aly AS (2014) Immobilization and characterization of inulinase from Ulocladium atrum on nonwoven fabrics Journal of biosciences 39:785793

Mutneja R, Singh R, Kaur V, Wagler J, Fels S, Kroke E (2016) Schiff base tailed silatranes for the fabrication of functionalized silica based magnetic nano-cores possessing active sites for the adsorption of copper ions New Journal of Chemistry 40:1640-1648

Naghdi M, Taheran M, Brar SK, Kermanshahi-pour A, Verma M, Surampalli RY (2018) Removal of pharmaceutical compounds in water and wastewater using fungal oxidoreductase enzymes Environmental pollution 234:190-213 
Namdeo M (2018) Magnetite Nanoparticles as Effective Adsorbent for Water Purification: A Review Advances in Recycling \& Waste Management 2:126-129

Nanayakkara S, Zhao Z, Patti AF, He L, Saito K (2014) Immobilized horseradish peroxidase (I-HRP) as biocatalyst for oxidative polymerization of 2, 6-dimethylphenol ACS Sustainable Chemistry \& Engineering 2:1947-1950

Pandey VP, Awasthi M, Singh S, Tiwari S, Dwivedi UN (2017) A comprehensive review on function and application of plant peroxidases Biochem Anal Biochem 6:308

Pasternack RM, Rivillon Amy S, Chabal YJ (2008) Attachment of 3-(aminopropyl) triethoxysilane on silicon oxide surfaces: dependence on solution temperature Langmuir 24:12963-12971

Pereira M, Oliveira L, Murad E (2012) Iron oxide catalysts: Fenton and Fentonlike reactions-a review Clay minerals 47:285-302

Petcharoen K, Sirivat A (2012) Synthesis and characterization of magnetite nanoparticles via the chemical co-precipitation method Materials Science and Engineering: B 177:421-427

Phan NT, Jones CW (2006) Highly accessible catalytic sites on recyclable organosilane-functionalized magnetic nanoparticles: An alternative to functionalized porous silica catalysts Journal of Molecular Catalysis A: Chemical 253:123-131

Prasad C, Yuvaraja G, Venkateswarlu P (2017) Biogenic synthesis of Fe304 magnetic nanoparticles using Pisum sativum peels extract and its effect on magnetic and Methyl orange dye degradation studies Journal of Magnetism and Magnetic Materials 424:376-381

Ramalingam B, Parandhaman T, Choudhary P, Das SK (2018) Biomaterial functionalized graphenemagnetite nanocomposite: a novel approach for simultaneous removal of anionic dyes and heavy-metal ions ACS Sustainable Chemistry \& Engineering 6:6328-6341

Rudra S, Shivhare U, Basu S, Sarkar B (2008) Thermal inactivation kinetics of peroxidase in coriander leaves Food and Bioprocess Technology 1:187-195

Sahoo JK, Paikra SK, Mishra M, Sahoo H (2019) Amine functionalized magnetic iron oxide nanoparticles: synthesis, antibacterial activity and rapid removal of Congo red dye Journal of Molecular Liquids 282:428-440

Sheldon RA, van Pelt S (2013) Enzyme immobilisation in biocatalysis: why, what and how Chemical Society Reviews 42:6223-6235

Tang T, Fan H, Ai S, Han R, Qiu Y (2011) Hemoglobin (Hb) immobilized on amino-modified magnetic nanoparticles for the catalytic removal of bisphenol A Chemosphere 83:255-264 
Tonami H, Uyama H, Nagahata R, Kobayashi S (2004) Guaiacol oxidation products in the enzyme-activity assay reaction by horseradish peroxidase catalysis Chemistry letters 33:796-797

Tupper J, Stratford M, Hill S, Tozer G, Dachs G (2010) In vivo characterization of horseradish peroxidase with indole-3-acetic acid and 5-bromoindole-3-acetic acid for gene therapy of cancer Cancer gene therapy $17: 420-428$

Venkateswarlu S, Rao YS, Balaji T, Prathima B, Jyothi N (2013) Biogenic synthesis of Fe304 magnetic nanoparticles using plantain peel extract Materials Letters 100:241-244

Vineh MB, Saboury AA, Poostchi AA, Mamani L (2018a) Physical adsorption of horseradish peroxidase on reduced graphene oxide nanosheets functionalized by amine: A good system for biodegradation of high phenol concentration in wastewater International Journal of Environmental Research 12:45-57

Vineh MB, Saboury AA, Poostchi AA, Rashidi AM, Parivar K (2018b) Stability and activity improvement of horseradish peroxidase by covalent immobilization on functionalized reduced graphene oxide and biodegradation of high phenol concentration International journal of biological macromolecules 106:1314-1322

Xu Q, Wang M Effect of electric field on horseradish peroxidase activity and its structure. In: 2010 3rd International Conference on Biomedical Engineering and Informatics, 2010. IEEE, pp 1307-1309

Yang K-L (2017) Combined cross-linked enzyme aggregates of horseradish peroxidase and glucose oxidase for catalyzing cascade chemical reactions Enzyme and Microbial Technology 100:52-59

Yang Y, Zhao M, Yao P, Huang Y, Dai Z, Yuan H, Ni C (2018) Comparative Studies on Enzyme Activity of Immobilized Horseradish Peroxidase in Silica Nanomaterials with Three Different Shapes and Methoxychlor Degradation of Vesicle-Like Mesoporous SiO2 as Carrier Journal of nanoscience and nanotechnology 18:2971-2978

Zhang Y, Wu H, Huang X, Zhang J, Guo S (2011) Effect of substrate (ZnO) morphology on enzyme immobilization and its catalytic activity Nanoscale research letters 6:1-7

Zhu H, Hu Y, Jiang G, Shen G (2011) Peroxidase-like activity of aminopropyltriethoxysilane-modified iron oxide magnetic nanoparticles and its application to clenbuterol detection European Food Research and Technology 233:881

\section{Figures}




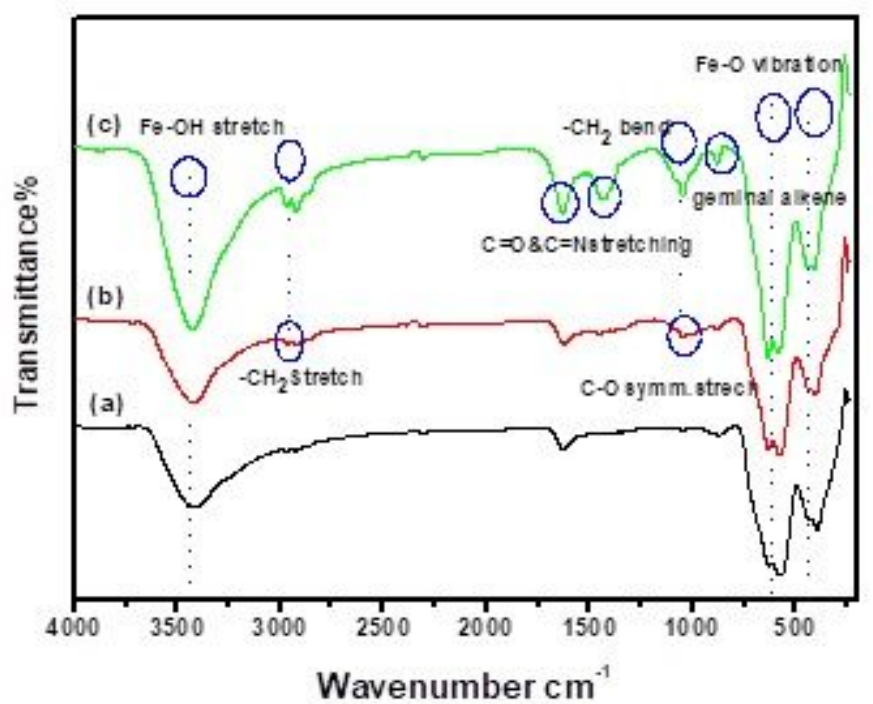

Figure 1

Represents FT-IR spectra of (a) Fe304, (b) Fe304@NH2, and (c) Fe3O4@NH2-HRP.

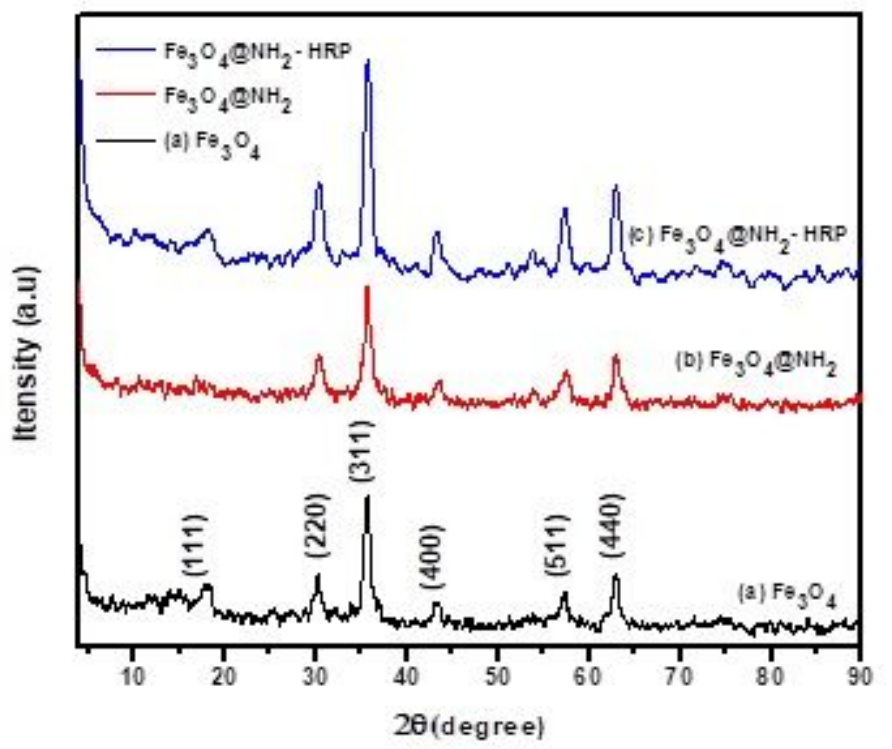

Figure 2

XRD pattern of (a) Fe304, (b) Fe304@NH2, and (c) Fe304@NH2-HRP. 


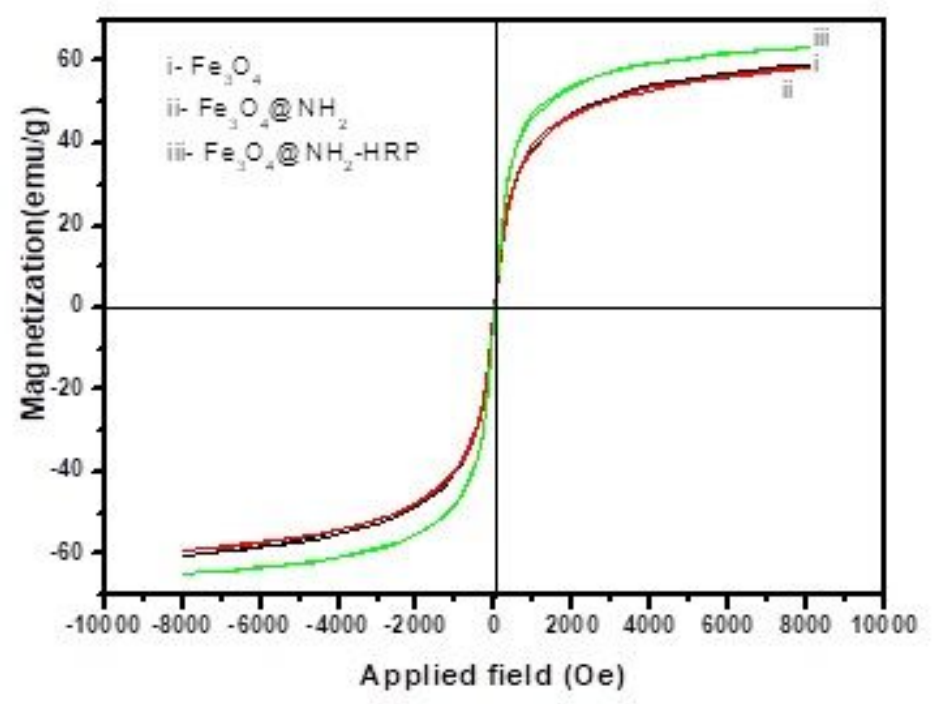

Figure 3

VSM hysteresis loop of (i) Fe304, (ii) Fe304@NH2, and (iii) Fe3O4@NH2-HRP.

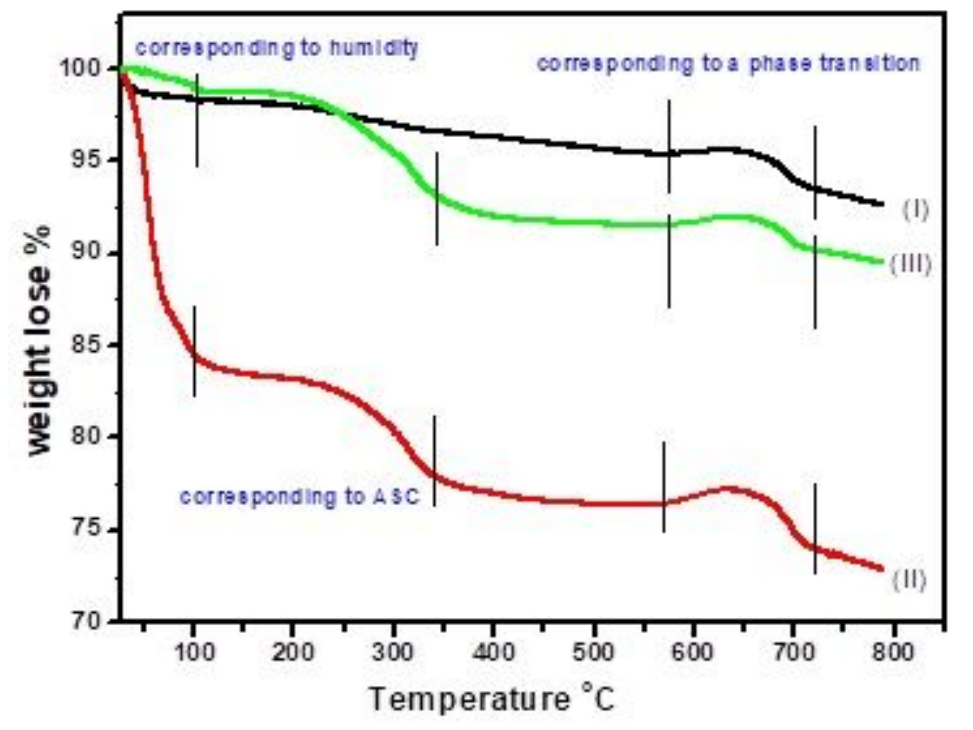

Figure 4

TGA curves of (I) Fe304, (II) Fe304@NH2, and (III) Fe304@NH2-HRP. 

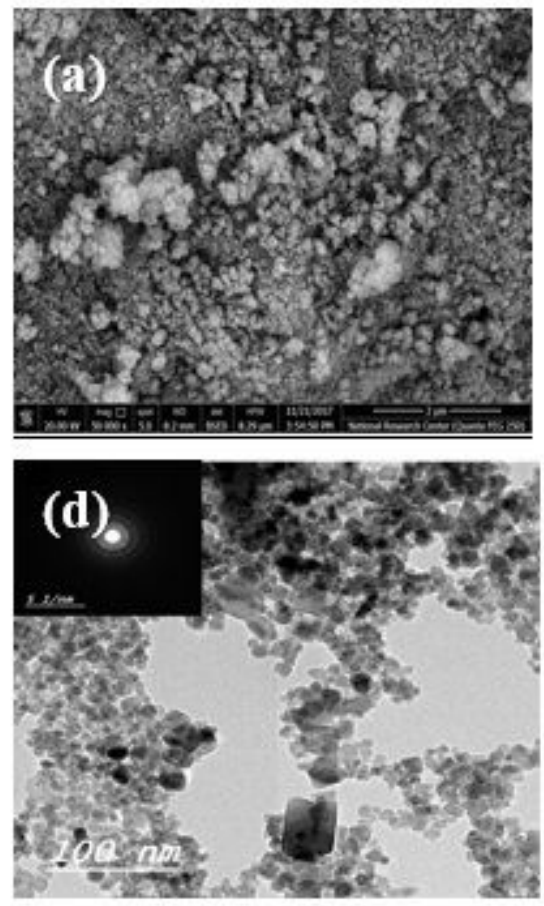
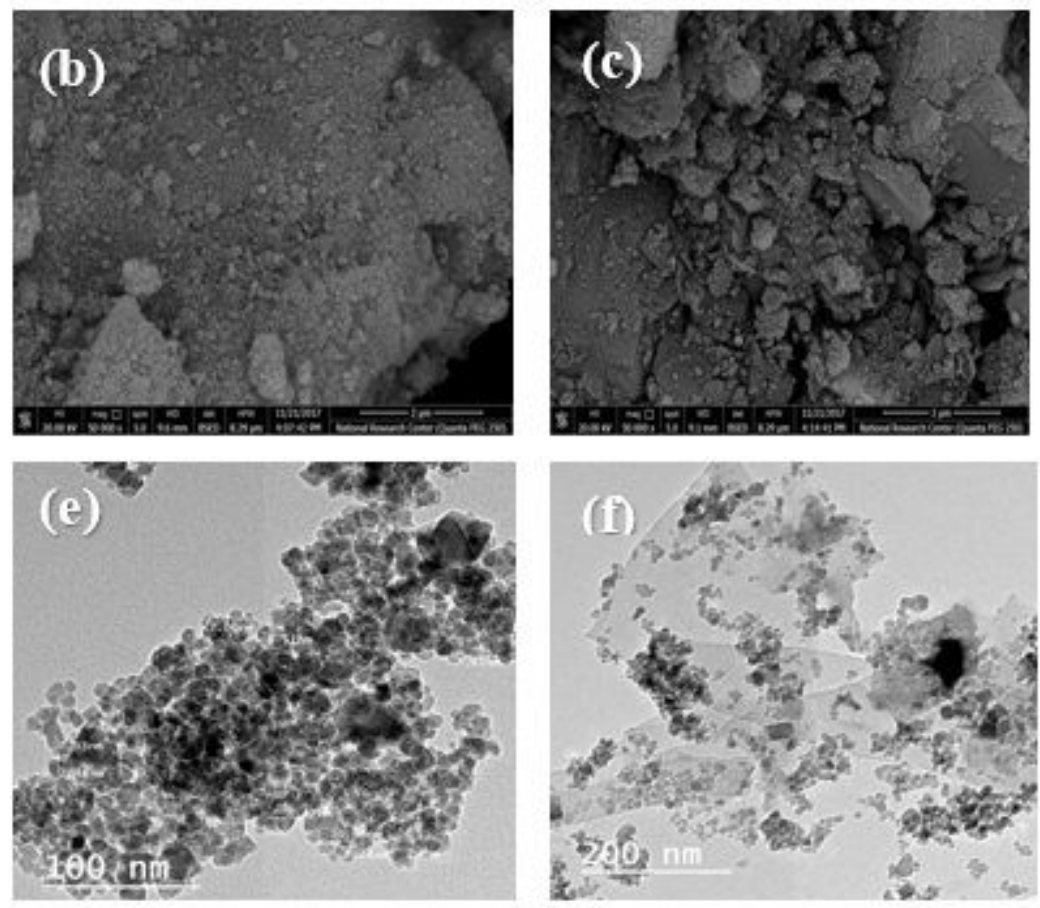

\section{Figure 5}

represents SEM images of (a) Fe304, (b) Fe304@NH2, and (c) Fe304@NH2-HRP and TEM images of (d) Fe304, (e) Fe304@NH2, and (f) Fe304@NH2-HRP.

a

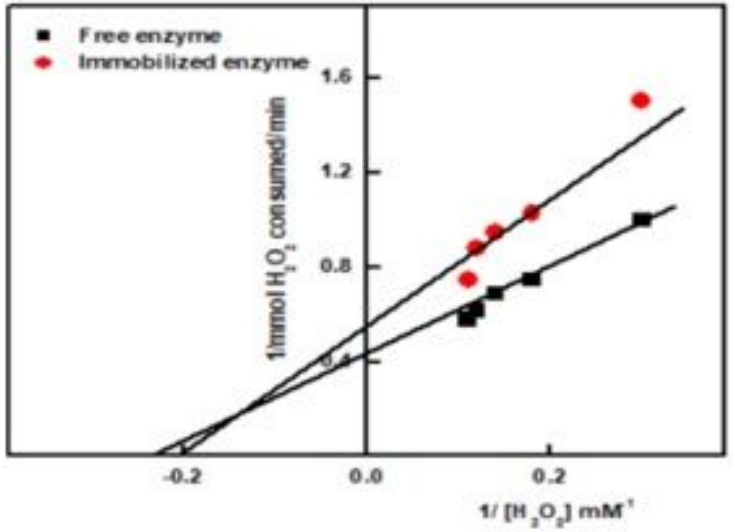

b

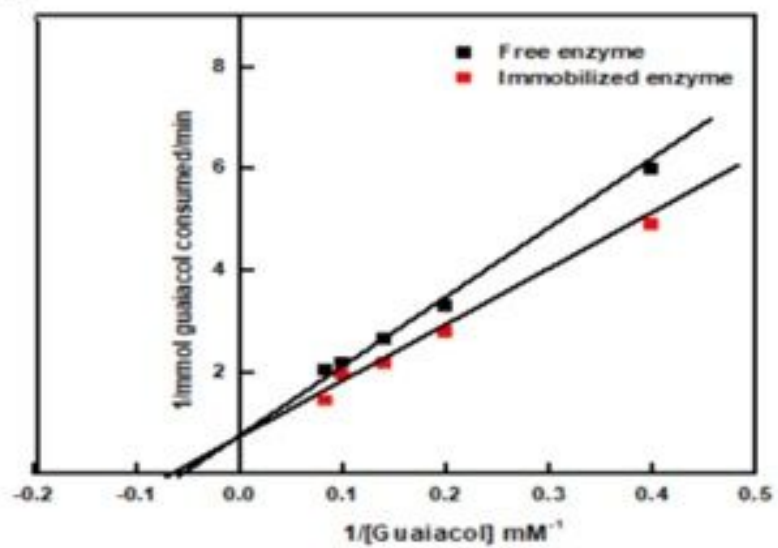

Figure 6

Lineweaver-Burk plots relating to free enzyme and immobilized HRP reaction velocity to (a) $\mathrm{H} 2 \mathrm{O} 2$ and (b) guaiacol concentrations. 

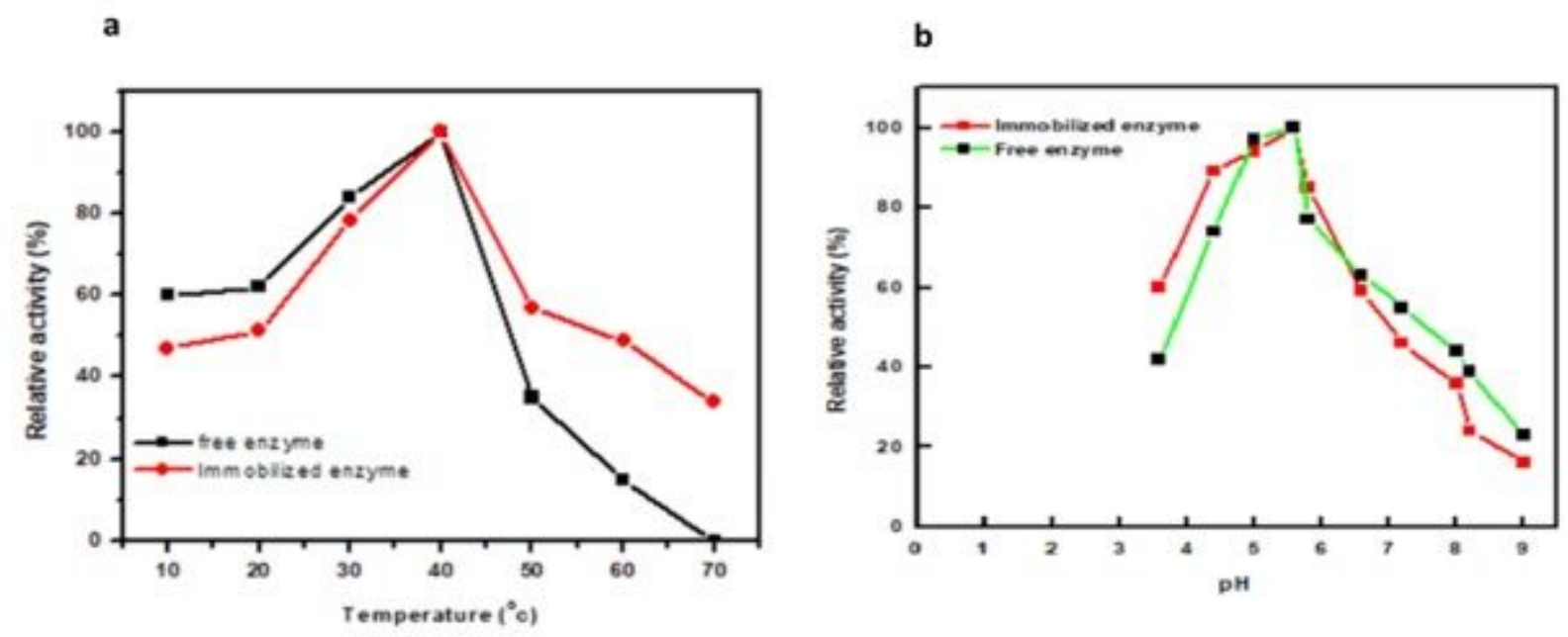

Figure 7

a- Graphical representations of temperature effects of the soluble and immobilizing peroxidase enzyme at various temperatures ranging from 10 to $70^{\circ} \mathrm{C}$. b- Optimum $\mathrm{pH}$ of the reaction mixture contain $1.0 \mathrm{ml}$ of $50 \mathrm{mM}$ sodium citrate $(\mathrm{pH} 3.0-4.0)$, sodium acetate $(\mathrm{pH}$ 5.0-5.6), sodium phosphate buffer ( $\mathrm{pH}$ 6.08.0), and Tris- $\mathrm{HCl}$ buffer $(\mathrm{pH} 9)$ and $8 \mathrm{mM} \mathrm{H} 2 \mathrm{O} 2,40 \mathrm{mM}$ guaiacol, and 0.1 unit enzyme were included in the reaction mix.

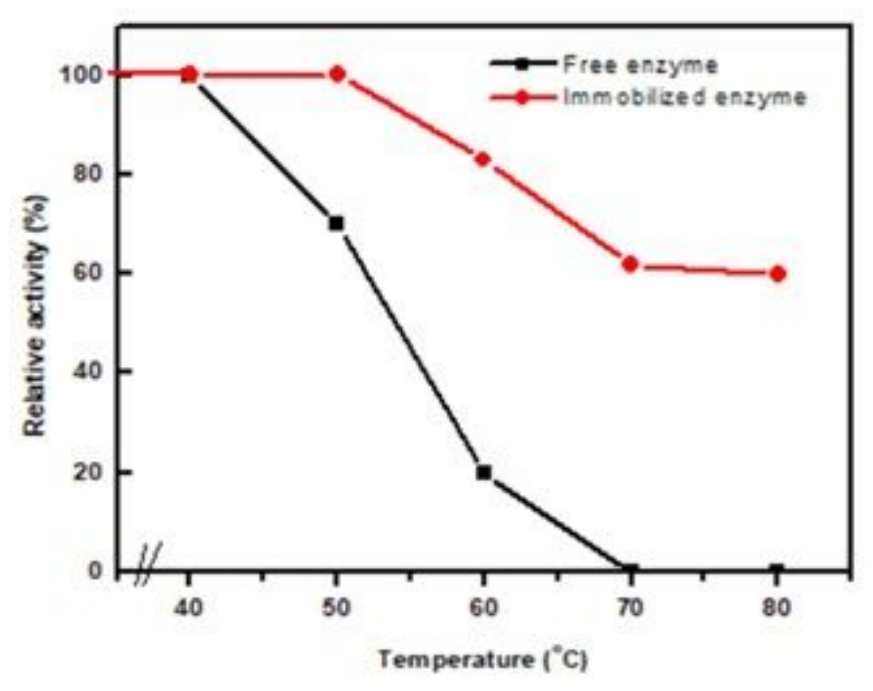

Figure 8

Graphical representation of the thermal stability of soluble and immobilized HRP by the temperature effect. In the $1.0 \mathrm{ml}$, a $50 \mathrm{mM}$ sodium acetate buffer $\mathrm{pH}$ of 5.6, $40 \mathrm{mM}$ guaiacol, $8 \mathrm{mM} \mathrm{H} 2 \mathrm{O} 2$, and an enzyme unit of 0.1 included a reaction mixture. At different temperatures between 10 and $80^{\circ} \mathrm{C}$ before the addition of the substrate for $30 \mathrm{~min}$, the reaction mix was pre-incubated then cooled down in an ice bath. 100 percent activity was taken as a zero-time activity for soluble and immobilized HRP. 


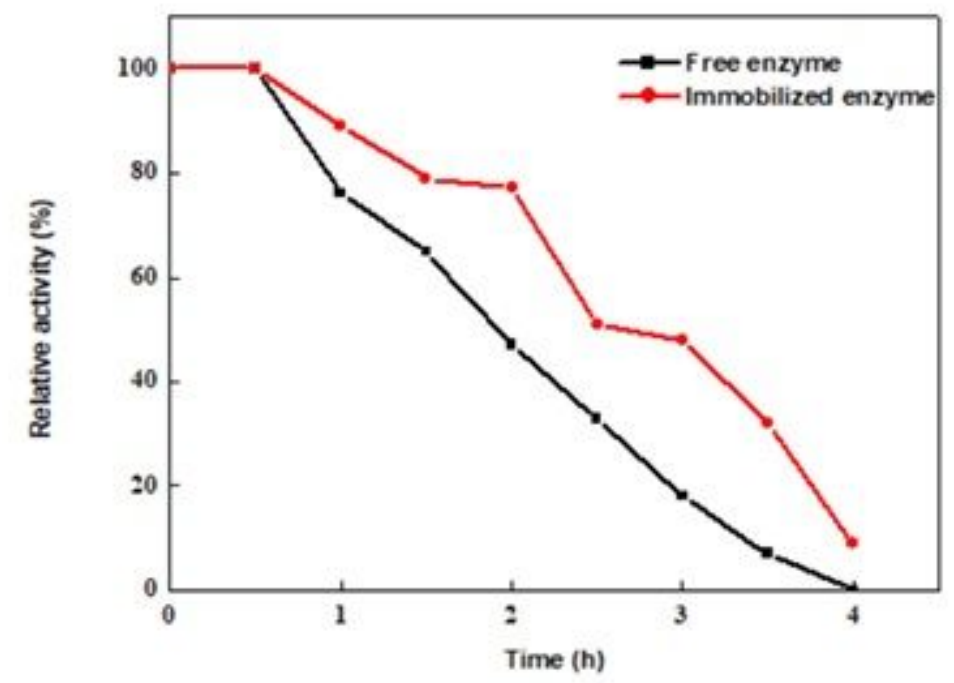

Figure 9

Graphical representation of the time intervals in optimum temp at $30^{\circ} \mathrm{C}$ for immobilized and free enzyme

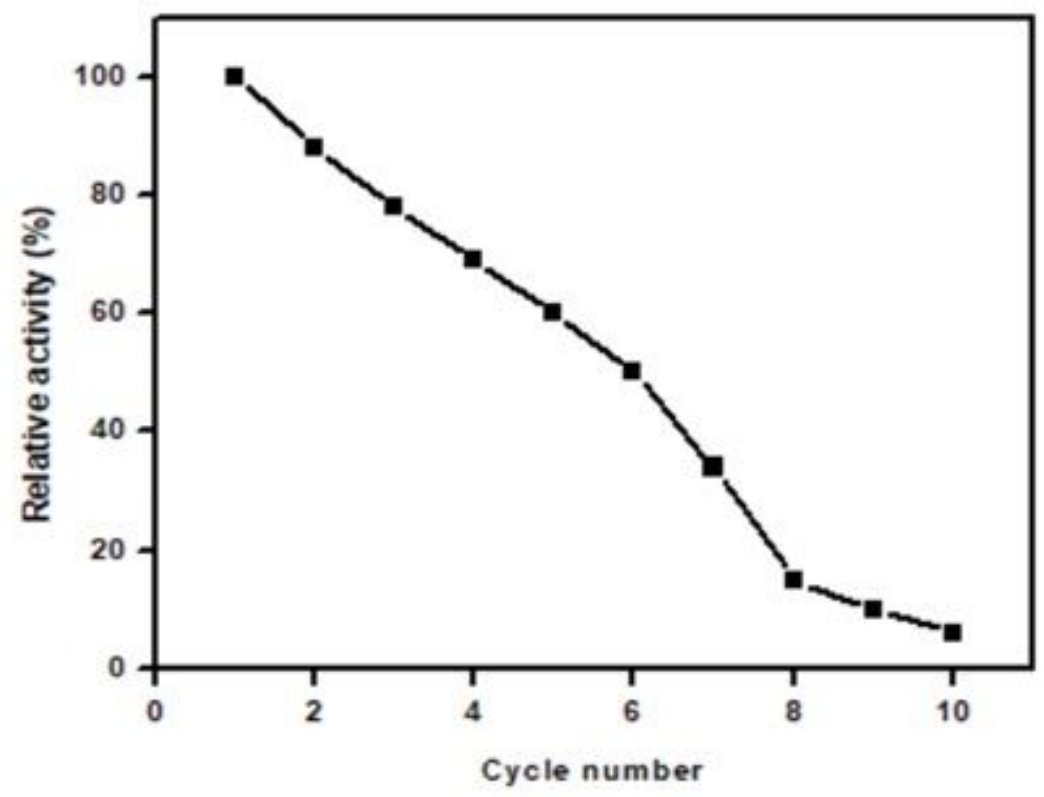

Figure 10

Graphic representation of immobilized peroxidase enzyme reusability on APTMS by being washed repeatedly following each test. A $1.0 \mathrm{ml}$ of $8 \mathrm{mM} \mathrm{H} 202,40 \mathrm{mM}$ guaiacol, and $50 \mathrm{mM}$ sodium acetate buffer $\mathrm{pH} 5.6$ were included in the reaction mix. 


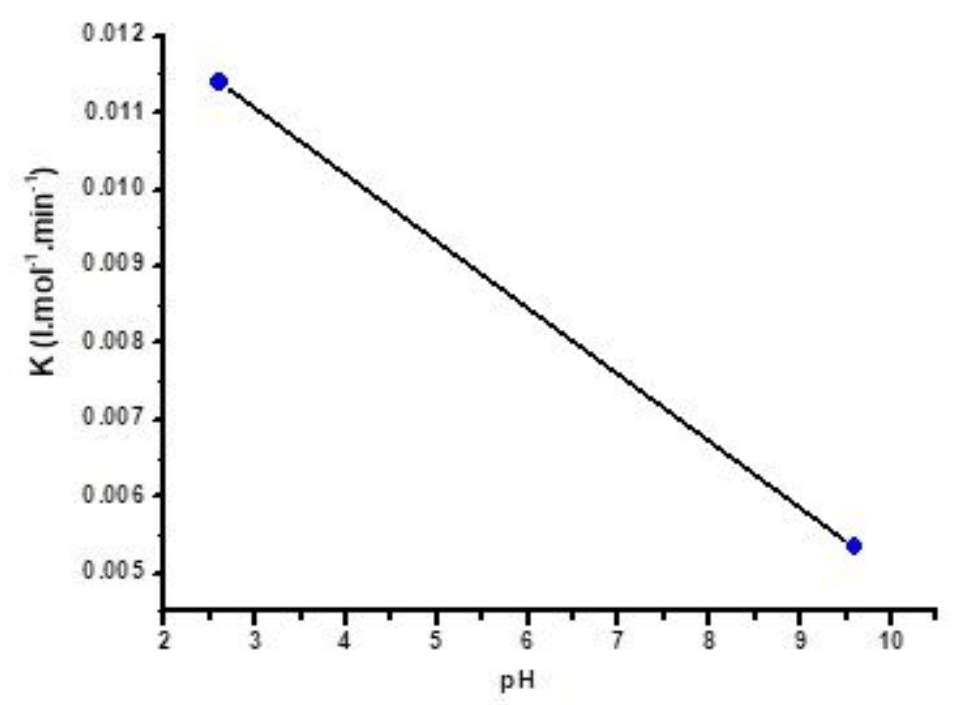

Figure 11

Dependency of the oxidation rate of $\mathrm{AB}$ on $\mathrm{pH},[\mathrm{AB}] \mathrm{o}=2.4 \times 10-4 \mathrm{~mol} \mathrm{~L}-1, \mathrm{Fe} 304 @ \mathrm{NH} 2-\mathrm{HRP}=300 \mathrm{mg} \mathrm{L}-1$, $[\mathrm{H} 2 \mathrm{O} 2] \mathrm{o}=0.16 \mathrm{~mol} \mathrm{~L}-1$ at $37^{\circ} \mathrm{C}$.

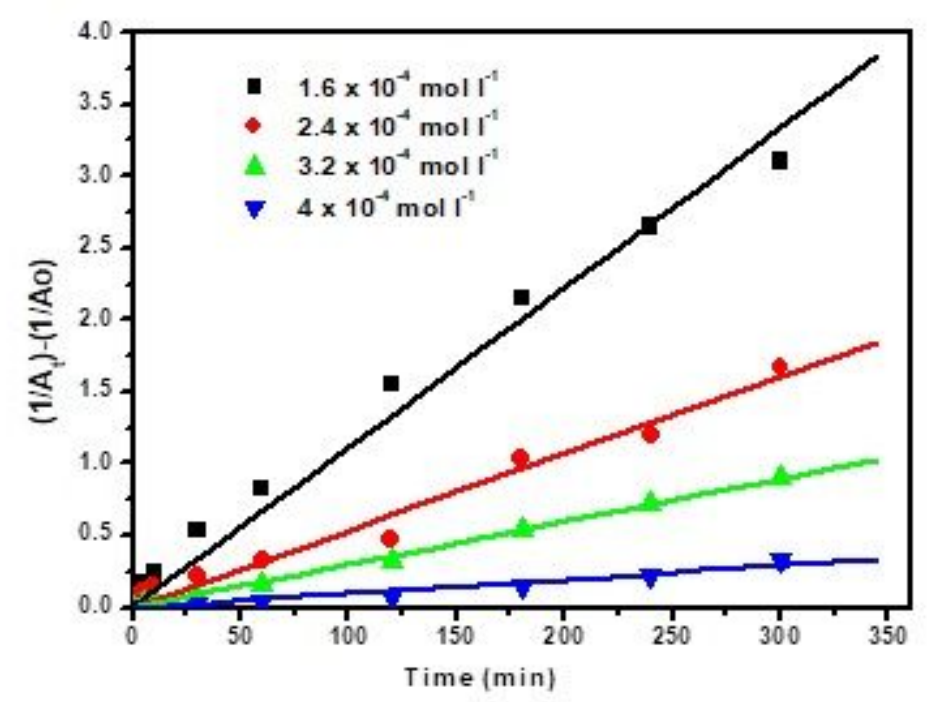

Figure 12

Second-order plots for the oxidative degradation of $[A B]$, Fe304@NH2-HRP $=300 \mathrm{mg} \mathrm{L-1},[\mathrm{H} 2 \mathrm{O} 2] \mathrm{o}=0.16$ $\mathrm{mol} \mathrm{L-1,} \mathrm{pH}=5.6$ at $37^{\circ} \mathrm{C}$. 


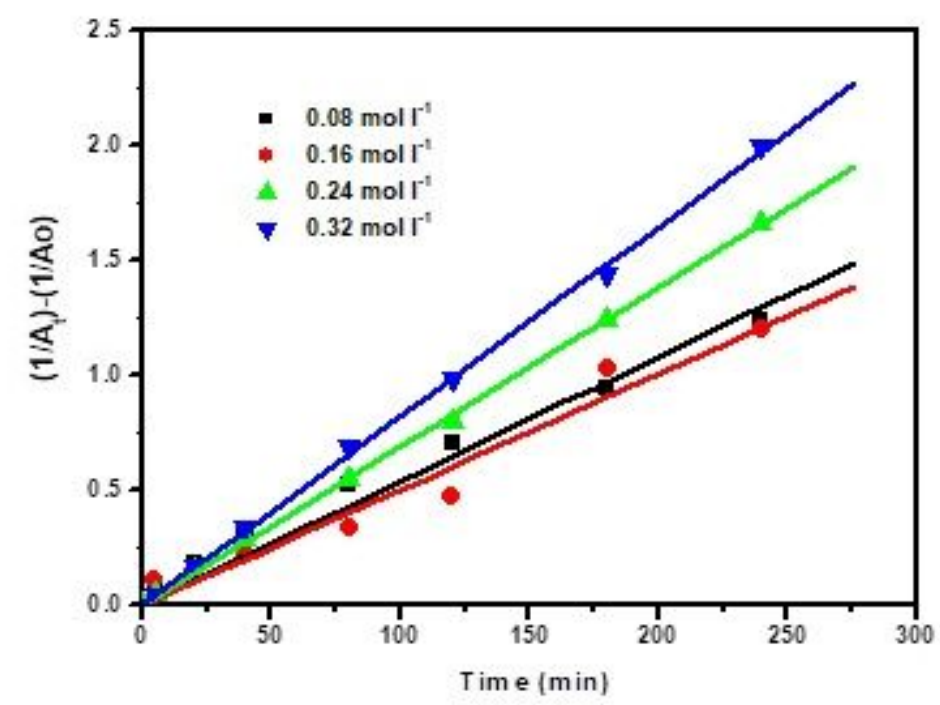

Figure 13

Second-order plots for Consumption of $A B$ dye as a function of time at different [H2O2], Fe304@NH2$\mathrm{HRP}=300 \mathrm{mg} \mathrm{L}-1,[\mathrm{AB}] \mathrm{o}=2.4 \times 10-4 \mathrm{~mol} \mathrm{~L}-1$ and $\mathrm{pH}=5.6$ at $37^{\circ} \mathrm{C}$.

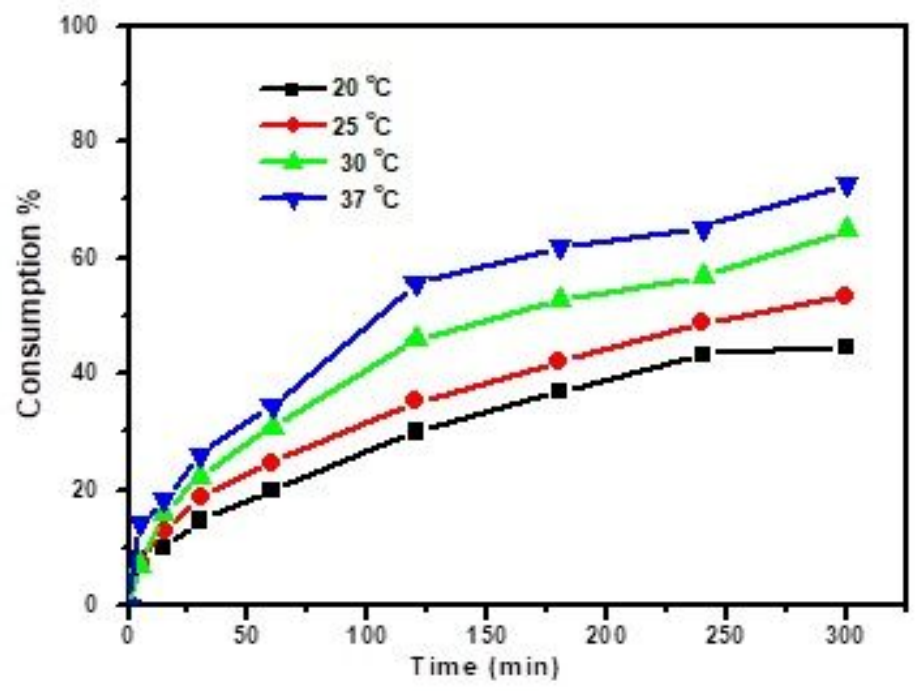

\section{Figure 14}

The consumption of $A B$ as a function of time at different temperatures. 


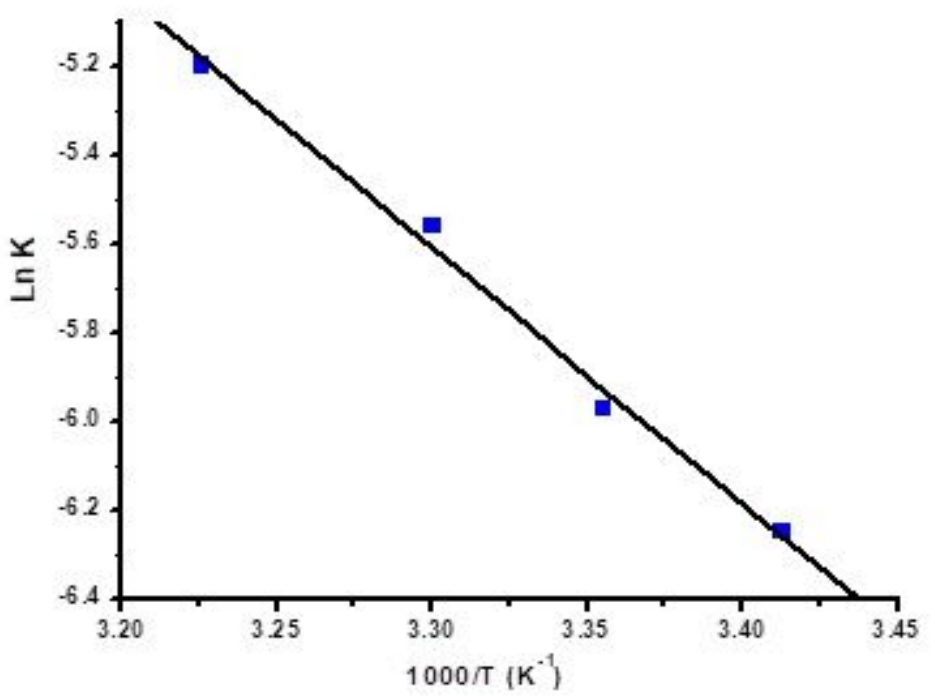

Figure 15

Eyring's plots for the oxidative degradation of AB with [H2O2]o = $0.16 \mathrm{~mol} \mathrm{L-1}$ and Fe304@NH2-HRP = $300 \mathrm{mg} \mathrm{L}-1$

\section{Supplementary Files}

This is a list of supplementary files associated with this preprint. Click to download.

- supplementarymaterials.docx 